\title{
Knowledge Transfer in University Quadruple Helix Ecosystems: An Absorptive Capacity Perspective.
}

\begin{abstract}
Increased understanding of knowledge transfer (KT) from Universities to the wider regional knowledge ecosystem offers opportunities for increased regional innovation and commercialisation. The aim of this paper is to improve the understanding of the KT phenomena in an open innovation context where multiple diverse stakeholders are interacting. An absorptive capacity-based conceptual framework is proposed, using a priori constructs which portrays the multidimensional process of KT between universities and its constituent stakeholders in pursuit of open innovation and commercialisation. Given the lack of overarching theory in the field, an exploratory, inductive theory building methodology was adopted using semi-structured interviews, document analysis and longitudinal observation data over a three year period. The findings identify various factors, namely human centric factors, organisational factors, knowledge characteristics, power relationships and network characteristics which mediate both the willingness of stakeholders to engage in KT and the effectiveness of knowledge acquisition, assimilation, transformation and exploitation. This research has implications for policy makers and practitioners by identifying the need to implement interventions to overcome the barriers to KT effectiveness between quadruple stakeholders to be able to more fully develop an open innovation ecosystem.
\end{abstract}

\subsection{Introduction}

This paper focuses on the role knowledge plays in commercialisation, within a University knowledge ecosystem context and explores how to improve the effectiveness of knowledge transfer (KT) from universities. Traditionally, university KT and Knowledge Exchange 
comprised of the 'pushing' or brokering of discipline-specific research outputs and/or the provision of more generalised education and skills development (Etzkowitz and Klofsten, 2005; Urbano and Guerrero, 2013). However, in recent years, universities have been required to take on a more entrepreneurial role as core actors within regional innovation ecosystems resulting in new and diverse opportunities for KT (Ambros et al, 2008; Etzkowitz, 2008; Arnkil et al, 2010; Hewitt-Dundas, 2012). Whilst this triple helix 'ecosystem' approach is purported to be one of the core elements of regional economic growth, within a knowledge-based economy (Nambisan and Sawhney, 2007; Urbano and Guerrero, 2013) a number of studies suggest that this largely normative KT process has not and is not delivering the expected levels of commercialisation in terms of GDP and increased jobs (Asheim and Coenen, 2005; Lawler, 2011). Cooke (2005), Arnkil et al (2010) and Kenney and Mowery (2014) suggest that from an open innovation perspective, the normative and primarily closed innovation through Triple Helix-based KT process adds to the 'internalisation' or isolation of knowledge rather than enabling more widespread opportunities for knowledge as a source of innovation. More recently user-driven innovation models have emerged, which add a fourth stakeholder group to the triple helix model. This approach recognises the increased role that end-users and therefore society are playing in regional and project-based innovations. These end-users in essence create the 'pull' or demand for innovation which can lead to opportunities for open innovation (Arknil et al., 2010; Carayannis and Rakhmatullin, 2014).

Alexander et al. (2012) suggests that the changing role of universities within a complex open innovation ecosystem of diverse stakeholders poses considerable challenges for effective KT. However, this is currently an underexplored area which is in need of improved understanding and conceptualisation as to how knowledge can be effectively transferred within an open innovation context (Holi et al., 2008; Chesbrough, 2011; Carayannis and Rakhmatullin, 2014). 
The aim of this paper is to improve the understanding of the KT phenomena in an open innovation context where multiple diverse stakeholders are interacting. To achieve this aim, an ex ante framework, derived from literature on KT between multiple stakeholders and triple helix based innovation is proposed. It is then applied to an in-depth case study. The case study aims to stimulate co-creational commercialisation outputs in the quadruple helix context. Based on the empirical findings, the initial framework has been revised and an ex post framework presented to aid understanding and conceptualisation of the actual KT processes which take place within an open innovation context.

\subsection{Knowledge Transfer within an Open Innovation System}

Universities are increasingly viewed as a hub of new knowledge (Leydesdorff, 2011). In recent years they have been expected to take on a more entrepreneurial role in KT within the regional knowledge ecosystem (Etzkowitz and Leydesdorff, 2000; Urbano and Guerrero, 2013) whereby they are considered a core conduit for regional KT and innovation through their engagement in commercialisation activities (Van Looy et al., 2011).

Arnkil et al., (2010) suggest that the presence of a university and supporting regional innovation strategy (RIS) does not guarantee that KT will take place, rather it attempts to create conducive conditions for KT and more radical innovation and commercialisation within the regional innovation ecosystem (Leydesdorff, 2012). Indeed, despite numerous governmental reports and initiatives over the past decade encouraging collaborations between triple helix stakeholders (e.g. Lambert Review, 2003; DTI, 2004; Sainsbury 2007; Wilson, 2012), key KT challenges in this context remain. 
KT within the Triple Helix is conceptualised as boundary spanning across academia, Industry and regional Government (Etzkowitz et al., 2000; Etzkowitz and Klofsten, 2005). However, with the emergence of the knowledge economy, and a network based knowledge ecosystem leading to quadruple helix structures, KT is deemed to be a both an entrepreneurial process (Dakin and Lindsey, 1991) and a valorisation process (Leloux et al., 2009) in the context of open innovation ecosystems.

\subsection{Conceptualising Knowledge Transfer between multiple stakeholders using an}

\section{Absorptive Capacity lens}

KT has been explored in a wide variety of practice based contexts however, there is a lack of an overarching or unified theory within the field (Chesbrough, 2011) reflecting its relative immaturity (Mitton et al, 2007; Arnkil et al., 2010; Carayannis and Rakhmatullin, 2014). Hence there is a need for improved conceptualisation. We suggest building on the conceptualisation of Su et al. (2013) who identify that an absorptive capacity lens can be used within an inductive theory building study to explore the process of KT. Absorptive Capacity has been used to explore why some organisations transfer knowledge more successfully than others, particularly in regards to University based KT within an open innovation ecosystem (Easterby-Smith et al., 2008; McAdam et al., 2010). Furthermore, Absorptive Capacity is seen as playing a crucial role in intra and inter-organisational knowledge transfer (Zahra and George, 2002; Lane et al., 2006). Hence following Su et al. (2013) Absorptive Capacity is put forward as a core construct in an initial ex ante theoretical framework.

Absorptive Capacity is defined as the ability to recognize, assimilate and apply new external knowledge to advance commercialisation and competitiveness (Cohen and Levinthal, 1990) and is viewed as a knowledge-based capability (Zahra and George, 2002). Knowledge sources 
and recipients (i.e. stakeholders within an open innovation ecosystem) may vary in their Absorptive Capacity levels and hence this may impact KT effectiveness between organisations (Cohen and Levinthal, 1990; Zahra and George, 2002; Todorova and Dursin, 2007; Su et al., 2013). In particular, Easterby-Smith et al., (2008) and McAdam et al., (2010) identify that Absorptive Capacity has become a useful construct to understand why some organisations develop more innovative products and are more successful at innovation activities than others (Easterby-Smith et al., 2008; McAdam et al., 2010). There is a paucity of studies using absorptive capacity constructs to explore KT processes within a quadruple helix knowledge ecosystem where an open innovation climate of inflows and outflows of knowledge coexist (Arnkil et al., 2010; McAdam et al., 2012). Hence there is an opportunity to at least partially address this knowledge gap and facilitate theoretical development and refinement through using absorptive capacity as a lens to explore the process of $\mathrm{KT}$ from universities to its respective stakeholders within an open innovation ecosystem (Easterby-Smith et al., 2008; McAdam et al., 2010).

\subsection{Ex Ante Model Development}

An ex ante model was developed using a priori concepts as suggested by Bendassolli (2013) from the extant literature. Figure 1 presents the ex ante model which uses an absorptive capacity lens to portray the process of knowledge acquisition, assimilation, transformation and exploitation (Zahra and George, 2002). Figure 1 suggest that KT from universities for commercialisation traditionally happens within a complex network of triple helix stakeholder interactions however, a knowledge validation decision needs to take place or what Zahra and George (2002) deem an 'activation trigger' to begin the process of KT. The KT literature identifies a number of influencing factors which can impact the effectiveness of KT. These can be grouped into the characteristics of the knowledge source and recipient, properties of 
knowledge, network characteristics and organisation context (Szulanski, 1996; Gupta and Govindarajan, 2000; Rothaermel et al., 2007; Matzler and Meuller, 2011).

[Insert figure 1 around here]

Once 'buy in' has been achieved absorptive capacity is needed to recognise the value of new knowledge, acquire, assimilate, transform and apply that knowledge to commercial ends (Cohen and Levinthal, 1990; Zahra and George, 2002). Similar to the knowledge validation decision, figure 1 identifies that capability development is mediated by various factors which are said to have varying impact on how knowledge flows between stakeholders at each KT stage (Zahra and George, 2002). Whilst a number of barriers and enablers to KT have been identified forming this conceptual model, the lack of overarching theoretical conceptualisation (Chesbrough, 2011) stresses the need for exploratory and inductive theory building to gain further understanding of the process of KT (Holi et al., 2008). This is particularly important when moving from a triple helix to a Quadruple Helix context in progressing towards effective mechanisms for open innovation and commercialisation (Sharifi and Liu, 2010; Alexander et al., 2012).

Based on the conceptual framework shown in figure 1, and the move from triple helix to quadruple helix structures within regional innovation systems, identifying a new stakeholder group, namely end users, three main questions have been identified. These were the cornerstones of the empirical phase of our research, where we explored in-depth the applicability of the framework in an open innovation quadruple helix context.

RQ1) What factors enable or prevent university KT effectiveness in relation to the absorptive capacity constructs of knowledge acquisition, assimilation, transformation and exploitation? 
RQ2) What role do quadruple helix stakeholder relationships play in progressing KT through the absorptive capacity constructs of knowledge acquisition, assimilation, transformation and exploitation in the context of open innovation and commercialisation?

RQ3) How can KT theory and practice be progressed through empirical findings demonstrating the relevance and further development of a absorptive capacity lens to depict the multidimensional nature of the process of KT amongst multiple stakeholders.

\subsection{Research Methodology}

In order to scrutinise the conceptual model based on a priori concepts (Bendassolli, 2013), an interpretivist, qualitative methodology was employed in order to inductively build theory in an under researched context. To facilitate in-depth, nuanced understanding in order to refine the conceptual model, one intrinsic case study (Stake, 2000) of a University was undertaken. Fromhold-Eisebith and Weker (2013) identify that the idiosyncratic nature of universities and their complex processes is best explored through single intrinsic case studies. Data was collected longitudinally over a period of 3 years, through in-depth semi-structured interviews (Yin, 2011) and observational analysis of KT meetings which happened monthly and comprised of internal and external stakeholders involved in the case university's KT activities. Appendix one presents the profile of the interviewees and their respective codes. In addition,

publically available documents were analysed relating to KT from universities and regional quadruple helix stakeholder collaborations, in order to gain a holistic view of the area under study (Eisenhardt, 1989; Yin, 2011). These documents included governmental strategies and white papers focused on collaborative KT between universities and quadruple helix stakeholders for the purposes of innovation. 


\subsection{Results and Discussion}

Based on the empirical findings, Figure 2 presents the ex post model of KT from universities from an absorptive capacity lens. This model presents the dynamic interaction between the quadruple helix stakeholders within the case study and thus aids refinement of the enablers and challenges of KT within an open innovation context.

\subsection{Quadruple helix stakeholder knowledge transfer with the aim of commercialising university research}

Figure 2 shows that the commercialisation of knowledge from the case university is increasingly becoming a collaborative process whereby universities, industry, government and end users were increasingly engaging in KT to help commercialise knowledge in an open innovation process (Alexander and Martin, 2013; Kenney and Mowery, 2014).

[Insert figure 2 around here]

It was noted by a KTO4 and recent policy documentation (RIS, 2014; DETI, 2014) that there was increasing pressure and financial incentives for the University to take a more central role within a quadruple helix open innovation ecosystem. Government dictated performance measures include, engagement in joint supervision projects, such as Knowledge Transfer Partnerships (KTPs), collaborative research and contract research. Moreover, engagement in co-creational KT to increase technology commercialisation effectiveness in the market place was now deemed to be core to regional and national innovation strategy (McAdam et al., 2012; Wilson, 2012; RIS, 2014). From the data it was identified that a number of enablers and challenges existed in relation to KT between stakeholders with the emergence of more open innovation processes. These are represented as latent factors within figure 2 and largely mirror the core enablers and barriers of KT identified from literature within the ex ante model which illustrates the ongoing importance of these factors when engaging in more open innovation 
practices. Each of the core enablers and barriers are summarised in table 1 and will be discussed in the sections which follow.

[Insert table 1 around here]

\subsection{Enablers and Challenges for effective Knowledge Transfer}

Whilst the core enablers and challenges within the case study appeared to align with prior literature, figure 2 differs from the ex ante model to show the interdependent nature of the latent factors which mediate both engagement in KT and the effectiveness of KT. It was found that a combination of those factors may have either a positive or negative impact on knowledge acquisition, assimilation, transformation and exploitation. Prior research often fails to represent the dynamic nature of factors which mediate the flow of knowledge between stakeholders (Volberda et al., 2010; McAdam et al., 2010), with Lee (2010) noting that KT is often taken for granted with less known about how absorptive capacity is created and developed.

\subsubsection{Human-centric Characteristics}

A number of personal characteristics and skills were found to affect stakeholders from engaging in $\mathrm{KT}$ and sharing (hence affecting knowledge validation, as shown in figure 2) and were also found to impact the effectiveness of knowledge acquisition, assimilation, transformation and exploitation when engaging with other stakeholders in the pursuit of open innovation and technology commercialisation. Concurring with prior literature, human-centric characteristics of stakeholders such as the ability to network and individual attitudes and traits were found to affect absorptive capacity (Cohen and Levinthal, 1990; Zahra and George, 2002; Walter et al., 2006; D’Este and Patel, 2007).

The networking capability of academic entrepreneurs within the case university was identified as a mediator of collaborative open innovation processes. Concurring with past research, it was 
identified that some academics have a lack of expertise which prevents them from engaging in effective networking and KT with industry (Lockett et al., 2003; Mosey and Wright, 2007). "Everyone have their own personal mechanisms for networking and I suppose academic scientists are not exactly known for their interpersonal skills... I don't think there is anything that can be done" (PI12). However, the importance of engaging in KT with industry and end users was identified as being useful in enhancing technology commercialisation (Audretsch and Feldman, 2003; McAdam et al., 2010). Stakeholder relationships were utilised to help understand and transform knowledge, aiding potential absorptive capacity (Zahra and George, 2002; Adams et al., 2006; McAdam et al., 2010). Furthermore the transformation of knowledge and consequently commercialisation (i.e. realised absorptive capacity, Zahra and George, 2002) was more successful when academic entrepreneurs had two-way flows of knowledge with industry networks and interaction with end users who helped to build awareness and interest in the innovations (Mitten et al., 2007; Livange et al., 2009).

Whilst it was evident that engagement with industry and end users had improved in recent years, cultural differences were still identified as a core barrier to effective KT (Goh, 2002; Easterby-Smith et al., 2008). However, the KTO staff perceived their role to be boundary spanning (Carlile, 2004) whereby they helped bridge interactions between academic entrepreneurs and industry, alleviating variances between cultures and processes (McAdam et al., 2010).

Within the case study, it was noted that intrinsic mind-sets and attitudes of individual stakeholders affected their willingness to engage in KT (Lucas and Ogilvie, 2006). It was recognised by all interviewees that within universities, academics are often working in academic silos, therefore there is a need for them to be opportunistic and to actively chat with 
external stakeholders to help the university fulfil their role as part of an open innovation ecosystem. PI5 notes "It is really up to us to engage with it and make an effort to meet different people and that is where the opportunities for collaboration arise". However, through the interviews and observation, it was unravelled that these mind-sets and attitudes to collaborate with industry and end users were largely a function of the organisational context, whereby organisational processes and mechanisms often shaped knowledge sharing behaviours (Szulanski, 1996; Bhagat et al., 2002; Laursen and Salter, 2006; Yeoh, 2009; Argote, 2012).

\subsubsection{Organisational factors}

It was evident that organisational factors played a key role in affecting knowledge absorption, sharing and transfer between the various stakeholders (see figure 2 and table 1). Organisational procedures and mechanisms were found to mediate stakeholder engagement and impact the effectiveness of KT (Urbano and Guerrero, 2013). For example, the emergence of a dedicated KTO identified the commitment of the university to develop internal procedures which enable academic entrepreneurs to engage in KT through open innovation activities. However, concurring with Locket et al., (2005) and Miller et al., (2014), the academic remit of teaching and producing high quality research publications was found to deter some academics from collaborating with external stakeholders. "They keep expecting more and more from us, I do not know how they expect us to teach, produce 3 and 4 star publications and have time to network with industry and engage in commercialisation when over 50\% of the time it does not result in something fruitful" (PI2). However, internal promotional mechanisms did appear to be changing with one academic (PI9) highlighting that they had received their senior lectureship by engaging in KT activities reflecting the universities efforts to change practices to embrace their entrepreneurial obligations in striving towards meeting government objectives (Bhagat et al., 2002; Lucas, 2006). 


\subsubsection{Knowledge characteristics}

The characteristics of the knowledge being transferred was found to influence its ability to be acquired, absorbed and exploited. Consistent with past research on KT (Siegel et al., 2003; Wright et al., 2009) the main type of knowledge being transferred during open innovation processes was business-related knowledge. This ranged from sales, marketing, finance, legal and experiential business knowledge; which has tacit and 'sticky' elements and is therefore often hard to acquire, transfer and absorb (Szulanski, 2002; Gourley, 2006). Hence the opportunity to increase collaboration of industry and end users at earlier stages of technology commercialisation processes was suggested as beneficial by the interviewees. It was recognised by the majority of the academics that having a good technology with a patent and protected IP was not enough "Having IP is almost immaterial because if you are a good sales person you can have dreadful IP but still sell" (PI11). This type of knowledge was thought to be based on personal attitudes, abilities and experience; therefore was difficult to acquire and absorb (Dyer and Singh, 1998; Nonaka and von Krough, 2009). Therefore it was identified that there was a need for academics to engage in open innovation processes with industry to help bridge this knowledge gap (Gassmann et al., 2010; McAdam et al., 2010). KTO staff were aware of academics deficiencies in knowledge "I know that whilst academics may be very good in their own research area and the specific areas they specialise in. Not very many of them have actually formed and sustained relationships with industry" (KTO3).

Furthermore, a scenario was identified by PI6 where they were engaging in open innovation with industry via mechanisms such as email and telephone. "We tried to do it remotely so we never actually met the people involved ...the project was full with problems ... our experience was that face to face communication is superior" (PI6). Thus it was noted that complex or 'sticky' knowledge, such as that required for innovation was said to require rich 
communication channels such as face to face communication to facilitate transfer and absorption (Szulanski, 2002; Yeoh, 2009; Alexander and Childe, 2012).

In prior studies, open communication has been found to reduce knowledge asymmetry (Vandekeckhove and Dentchev, 2005) which is essential when multiple diverse stakeholders are interacting in an open innovation context. However, the case study showed that with an increasing number of stakeholder's becoming involved in commercialisation processes, it was becoming increasingly difficult to negotiate and compromise on stakeholder objectives which are often diverse. Recent government policies (Wilson, 2012; RIS, 2014; DETI, 2014) identify the 'ideal' of co-creational KT in an open innovation quadruple helix ecosystem however, as noted previously, inherent organisation factors were found to constrain full engagement between universities, industry and end users.

\subsubsection{Power relationships}

It was noted throughout the research period that KT between multiple diverse stakeholders in pursuit of open innovation was complex and often difficult. Consistent with prior research (Easteby-Smith et al., 2008; McAdam et al., 2012), this source of conflict was often the result of varying aims and objectives governing KT. From the case study findings (and as shown in figure 2 and table 1) it was found that power relationships had an effect on both stakeholder willingness to engage in $\mathrm{KT}$ and the effectiveness of $\mathrm{KT}$, which will have a consequential impact on commercialisation success.

University remit was a reoccurring theme, whereby the need to publish often conflicted with the priorities and objectives of industry during collaborative innovation projects (Van Looy et al., 2011; Hewitt-Dundas, 2012). The KTO staff recognised this issue when trying to bridge 
KT between industry and academics; "well academic publications run directly counter to the commercialisation task. That is one of the great ironies at the heart of the academic research system!” (KTO3). However, it was identified that IP applications can be sough quite quickly thus it was thought that two way communication was needed to eliminate potential conflict between stakeholders (Nadler et al., 2003; Van Wijlk et al., 2008).

It was suggested by several academics and KTO staff that government do not fully understand the challenges involved in KT between universities, industry and end users in the pursuit of innovation; "...the nature of the stuff coming out of the universities labs at that stage is a very fragile concept and you can't directly take those things and in 6 months time be employing 100 people ... You are looking at ideas and discoveries which on the day that they are disclosed to us that no one can put their hand on their heart that that is worth investing in or not... They think it (referring to Government) is perhaps an automatic one rather than a kind of hand holding, steering, developing, mentoring type one" (KTO4). GOV2 admitted that there are a lot of bureaucracy governing quadruple stakeholder collaborations however, that this was driven by disappointing results from previous programmes and innovation strategies. It appeared that the KTO and Government were both trying to exert their power to influence how quadruple interactions should progress. However, drawing upon Mitchell et al. (1997) and Frooman, (1999) the more dominant stakeholder appeared to be government since they had the power to withhold/withdraw funding which potentially could affect the KT activities.

\subsubsection{Network characteristics}

As noted, with the emergence of the quadruple helix, there is increased pressure for more networked relationships between universities and their stakeholders (Arnkil et al., 2010; Carayannis et al, 2012). Within the case study it was identified that KT between universities, 
government, industry and end users was aided through the case university's KTO. The KTO staff considered their role to be invaluable in helping eliminate any cultural or language problems between diverse knowledge groups. Therefore the KTO appeared to be 'boundary spanners' and played an important role in aiding KT (Zahra and George, 2002; Tortoriello and Krackhardt, 2010).

The ability to effectively engage in KT was also found to be mediated by the need to build trust between stakeholders; however, this was considered to be challenging when dealing with diverse stakeholders, many of which interact in an ad-hoc manner (McAdam et al., 2012; Miller et al., 2014). Indeed, concurring with Levin and Cross (2004) and Szulanski et al. (2004) it was stressed that a lack of trust could potentially hinder knowledge sharing and transfer within open innovation commercialisation activities since it prevents knowledge openness. "I think it's important as a model for whatever academic community or social community who undertake with no hidden agendas, just for sheer joy of finding out what other people do and then having a one to one or whatever conversation with them that you are not going to steal their ideas. The trust has to be built before partnerships can foster" (PI14). The ability to build personal relationships was found to be essential to use not only as a source of prior knowledge but helped convert ideas into products and services. Thus building relationships and actively maintaining those relationships was found to facilitate access to knowledge (Miller et al., 2011).

\subsubsection{Learning from knowledge transfer}

In contrast to figure 1 , the feedback loop in figure 2 presents a continuous cyclical process where it was observed that KT and learning is cumulative and path dependent (Cohen and Levinthal, 1990; Lane et al., 2006). However, it was found that learning mechanisms within the case university required further development. Whilst it was evident that academics reflected 
on past commercialisation failures, there appeared to be a lack of internal systems and procedures which captured knowledge from past unsuccessful commercialisation efforts so that lessons could be learned for future KT efforts (Cohen and Levinthal, 1990; Easterby-Smith et al., 2008). Thus in the case study, single loop learning appeared to still prevail at the university level (Argyris and Schon, 1978) which could be considered a core barrier to KT since, the case university did not appear to alter their processes or policies as a result of 'lesson's learned' through prior KT with stakeholder in the pursuit of innovation.

\subsection{Conclusions and recommendations for further research}

Empirical studies on KT and absorptive capacity to date show serious shortcomings signalling the need for further conceptualisation and development (Holi et al. 2008; Chesbrough, 2011; Carayannis and Rakhmatullin, 2014). Indeed, in an open innovation context, where multiple diverse stakeholders are interacting, new challenges emerge (Chesbrough et al., 2006) identifying the need for improved knowledge and understanding of the processes of KT between multiple stakeholders. Within this article we aimed to contribute to this discourse by exploring how knowledge can be effectively transferred between universities and their constitute stakeholders within an open innovation quadruple helix context. The proposed model identifies a number of interdependent factors can enable or restrain KT effectiveness, namely human centric factors, knowledge characteristics, organisational factors, power relationships and network characteristics. These factors were found to both determine the initial decision to engage in $\mathrm{KT}$ and mediated the acquisition, assimilation, transformation and exploitation of knowledge when multiple stakeholders are engaging in commercialisation activities.

It was identified that an open innovation context presents significant challenges for KT where diverse stakeholder groups, each with organisational-specific traditions, experiences and 
idiosyncratic practices create specific challenges impacting KT effectiveness (Mitton et al., 2007; Fromhold-Eisebith and Weker, 2013). In particular, the impact of power relationships were found to significantly impact KT, where a dominant stakeholder can exert their power which impinges upon the balance of the quadruple helix and has the potential to affect KT behaviours. A defining feature of an effective quadruple helix is mutual interdependence between all stakeholders (Leydesdorff, 2012; Carayannis et al., 2012) however, it was evident in the case study that the different stakeholders often tried to exert their salience (Frooman, 1999; Miller et al, 2014) creating an imbalance of power. This contest for power had the ability to affected KT willingness, behaviours and effectiveness at all stages. Therefore there is a need to more fully identify and address power relationships in open innovation projects involving diverse stakeholders.

The empirical findings identified that the KTO played a key boundary spanning role in helping mediate relationships between the diverse stakeholders and helping progress KT through the absorptive capacity constructs of knowledge acquisition, assimilation, transformation and exploitation in the context of open innovation and commercialisation. Thus it is suggested that KT between diverse stakeholders demands intermediaries to help eliminate the barriers of KT (Howells, 2006; Mitton et al., 2007) and champion the value of KT.

Furthermore, the case study findings identified that that move from a triple helix to a quadruple helix ecosystem did appear to be beneficial to aid collaborative innovation efforts, with the role of industry and end users being viewed as important in helping progress from potential absorptive capacity to realised absorptive capacity. However, it was identified that the case university was still yet to fully embrace the concept of open innovation due to the overarching priorities of the academic remit of teaching, research and producing high quality publications 
which was limiting KT between the university and their constitute stakeholders (HewittDundas, 2010; Miller et al., 2014). For universities to fully embrace their core role in a quadruple helix ecosystem, more supportive organisational mechanisms facilitating academics to build relationships with industry and end users is needed.

Increased pressure from government for more collaborative open innovation processes between quadruple helix stakeholders (Ahonen and Hämäläinen, 2012; Leydesdorff, 2012), raises questions as to how KT can be effectively managed with an increased number of diverse stakeholders expected to mutually collaborate. Within this study, our model is useful since it helps conceptualises of the multidimensional nature of the process of KT and proposes that absorptive capacity is a meaningful construct to identify the flows of knowledge between diverse stakeholder groups in pursuit of open innovation practices. Within this research, a single case study approached was followed in order to explore the applicability of a priori concepts (Bendassolli, 2013). Single case study approaches do not lend themselves to empirical generalisation across different contexts (Yin, 2012) however, the proposed model and absorptive capacity constructs can be reinterpreted and reconstructed in varying contexts thus facilitating theoretical generalisation (Eisenhardt, 1989). It is suggested that future research should develop the proposed model into testable propositions to be used in other contexts where multiple stakeholders are engaging in KT thus facilitating empirical generalisation and development of the KT field. In addition, future research should also explore mechanisms and platforms which may help balance power relationships in an open innovation context which will help aid KT effectiveness and commercialisation success.

\section{References}

Adams, R., Bessant, J. and Phelps, R. (2006) Innovation management measurement: A Review. International Journal of Management Reviews, 8(1), 21-47. 
Ahonen, L., and Hämäläinen, T. (2012) CLIQ: A Practical Approach to the Quadruple Helix and More Open Innovation, Sustaining Innovation: Collaboration Models for a Complex World. SpringerLink: Bücher.

Alexander, A. T. and Childe, S. J. (2012) Innovation: a knowledge transfer perspective.

Production Planning and Control, 23, 1-18.

Alexander, A. T., Pearsons, S. R., Fielding, S. N. and Bessant, J. R. (2012) The Open Innovation Era. Are University Services up to the Challenge? In: BITRAN, I. and CONN, S. (eds.) The XXII ISPIM Conference-Action for Innovation: Innovating from Experience Barcelona, Spain: Wiley and Sons.

Alexander, A. T. and Martin, D. P. (2013) Intermediaries for open innovation: A competence based comparison of knowledge transfer offices practices. Technological Forecasting and Social Change, 80, 38-49.

Ambros, T.C. Makela, K., Birkinshaw, J., D’Este, P. (2008) When does university research get commercialised? Creating ambidexterity in research institutions. Journal of Management Studies, 45(8), 1424-1447.

Argote, L., McEvily, B. and Reagans, R. (2003) Managing Knowledge in Organizations: An Integrative Framework and Review of Emerging Themes. Management Science, 49(4), 571582.

Argote, L. (2012) Organisational Learning: Creating, Retaining and Transferring Knowledge. UK: Springer.

Arnkil R., Järvensivu A., Koski, P. and Piirainen, T. (2010) Exploring Quadruple Helix Outlining user-oriented innovation models. University of Tampere, Institute for Social Research, Work Research Centre. Available online: https://tampub.uta.fi/bitstream/handle/10024/65758/978-951-44-8209-0.pdf?sequence=1 (accessed 17/12/14).

Asheim, B.T. and Coenen, L. (2005) Knowledge bases and regional innovation systems: comparing Nordic clusters. Research Policy, 34(8), 1173-90.

Audretsch, D. and Feldman, M.P. (2003) Knowledge Spillovers and the Geography of Innovation in J. Vernon Henderson and Jacque Thisse, editors. Handbook of Urban and Regional Economics: Cities and Geography. Amsterdam: North Holland Publishing. pp. 27132739.

Bendassolli, P.F. (2013) Theory Building in Qualitative Research: Reconsidering the Problem of Induction. Forum Qualitative Sozialforschung, 14(1), 25-36. 
Bhagat, R.S., Kedia, B.L., Haveston, P.D. and Triandis, H.C. (2002) Cultural Variations in the Cross-Border Transfer of Organisational Knowledge: An Integrative Framework. Academy of Management Review, 27(2), 204-221.

Breznitz, S.M., O’Shea, R.P. and Allen, T.J. (2008) University commercialization strategies in the development of regional bio clusters. Journal of Product Innovation Management, 25, 129 142.

Campbell, E., Powers, J., Blumenthal, D. and Biles, B. (2004) Inside the triple helix: Technology transfer and commercialization in the life sciences. Health Affairs, 23, 64-76.

Carayannis, E. G., Rogers, E. M., Kurihara, K. and Allbritton, M.M. (1998) High technology spin-offs from government R\&D laboratories and research universities. Technovation, 18, 111.

Carayannis, E.G. and Rakhmatullin, R. (2014) The Quadruple/Quintuple Innovation Helixes and Smart Specialisation Strategies for Sustainable and Inclusive Growth in Europe and Beyond. Journal of the Knowledge Economy, 5(2), 212-239.

Carayannis, E.G., Barth, R.D., and Campbell, D.F.J. (2012) The quintuple helix innovation model: global warming as a challenge and driver for innovation. Journal of Innovation and Entrepreneurship, 1, 1-12.

Carlile, P.R. (2004) Transferring, Translating, and Transforming: An Integrative Framework for Managing Knowledge Across Boundaries. Organisational Science, 15(5), 55-568.

Chesbrough, H. (2011) Bringing open innovation to services. MIT Sloan Management Review, 52, 85-91.

Chesbrough, H., Vanhaverbeke, W. and West, J. (2006) Open Innovation: Researching a New Paradigm. Oxford: Oxford University Press.

Cohen, W.A. and Levinthal, D.A. (1990) Absorptive Capacity: A New Perspective on Learning and Innovation. Administrative Science Quarterly, 35(1), 128-152.

Cooke, P. (2004) Regional innovation systems: an evolutionary approach. In Cooke, P., Heidenreich, M. and Braczyk, H. (eds.), Regional Innovation Systems: The Role of Governance in a Globalized World, London: Routledge.

Cooke, P. (2005) Regionally asymmetric knowledge capabilities and open innovation: Exploring_Globalisation 2-A new model of industry organisation. Research Policy, 34, 1128-1149. 
Dakin, K.L. and Lindsey, J. (1991) Technology transfer: financing and commercializing the high tech product or service: from research to roll out. California: Probus Publishing Company.

DETI (2014) Innovation Strategy for Northern Ireland 2014-2025. Available online: http://www.detini.gov.uk/innovation-strategy-2014-2025_2.pdf (accessed 21/12/2014).

D'Este, P. and Patel, P. (2007) University-industry linkages in the UK: What are the factors underlying the variety of interactions with industry? Research Policy, 36(9), 1295.

DTI (2004) Science and Innovation Investment Framework 2004-2014. Available online: http://news.bbc.co.uk/nol/shared/bsp/hi/pdfs/science_innovation_120704.pdf $\quad$ (accessed 20/12/14).

Dyer, J. H. and Singh, H. (1998) The relational view: Cooperative strategy and sources of interorganizational competitive advantage. Academy of management review, 23(4), 660-679. Easterby-Smith, M., Lyles, M. A., and Tsang, E. W. K. (2008) Inter-organizational knowledge transfer: current themes and future prospects. Journal of Management Studies, 45, 677-690 Eisenhardt, K. (1989) Building theories from Case study research, Academy of Management Review, 14, 532-550.

Etzkowitz, H. (2008) The Triple Helix: University-Industry-Government Innovation in Action. London: Routledge.

Etzkowitz, H. and Klofsten, M. (2005) The innovating region: Toward a theory of knowledge based regional development. $R \& D$ Management, 35, 243-255.

Etzkowitz, H. and Leydesdorff, L. (2000) The dynamics of innovation: from national systems and 'Mode 2' to a triple helix of university-industry-government relations. Research Policy, 29, 109-23.

Etzkowitz, H., Webster, A., Gebhardt, C., Cantisano, B.R. (2000) The future of the university and the university of the future: Evolution of ivory tower to entrepreneurial paradigm,

Research Policy, 29, 313-330.

Fromhold-Eisebith, M. and Weker, C. (2013) Universities function in knowledge transfer: a geographical perspective. The Annals of Regional Science, 51(3), 621-643.

Gassmann, O., Enkel, E. and Chesbrough, H. (2010) The Future of Open Innovation. $R \& D$ Management, 40(3), 213-221.

Gibbons, M., Limoges, C., Nowotny, H., Schwartzman, S., Scott, P. and Trow, M. (1994) The new production of knowledge: the dynamics of science and research in contemporary societies. London: Sage. 
Goh, S.C. (2002) Managing effective knowledge transfer: an integrative framework and some practice implications. Journal of Knowledge Management, 6(1), 23 - 30.

Gourlay, S. (2006) Conceptualizing knowledge creation: a critique of Nonaka's theory. Journal of Management Studies, 43(7), 1415-1436.

Gupta, A.K. Govindarajan, V. (2000) Knowledge Flows within the Multinational

Corporation. Strategic Management Journal, 21, 473-496.

Hayes, R.H., Clark, K.B. (1985) Exploring the Sources of Productivity Differences at the Factory Level. New York: Wiley.

Hewitt-Dundas, N. (2012) Research intensity and knowledge transfer activity in UK Universities. Research Policy, 41(2), 262-275.

Holi, M., Wickramasinghe, R. and van Leeuwen, M. (2008) Metrics for the Evaluation of Knowledge Transfer Activities at Universities, UNICO Report. Available online: http://ec.europa.eu/invest-in-research/pdf/download_en/library_house_2008_unico.pdf (accessed 18/12/14).

Howells, J. (2006) Intermediation and the role of intermediaries in innovation. Research Policy, 35, 715-728.

Kenney, M. and Mowery, D. (2014) Public Universities and Regional Development: Insights from the University of California System. Palo Alto, CA, Stanford University Press.

Lane, P.J., Koka, B.R. and Pathak, S. (2006) The reification of absorptive capacity: A critical review and rejuvenation of the construct. Academy of Management Review, 31(4): 833-863.

Lambert. R. (2003) Lambert Review of Business-Industry Collaboration. Final Report, December, HMSO.

Laursen, K. and Salter, A. (2006) Open for Innovation: the role of openness in explaining innovation performance among U.K. manufacturing firms. Strategic Management Journal, 27, 131-50.

Lawler, C. (2011) The capitalisation of knowledge: a triple helix of university-industry government. Studies in Higher Education, 36, 746-747.

Lee, R. P. (2010) Extending the Environment-Strategy-Performance Framework: What Are the Roles of MNC Network Strength, Market Responsiveness, and Product Innovation. Journal of International Marketing, 18 (4), 58-73.

Lerner, J. (2005) The University and the Start-up: lessons from the past two decades. Journal of Technology Transfer, 30(1/2), 49-56. 
Leloux, M., van der Sijde, P. and Groen, A. (2009) 'The Evolutional Business Valuation of Technology Transfer', In Oakley, R., Groen, A., Cool, P. and van der Sijde, P. (eds.), New Technology-Based Firms in the New Millenium, London: Emerald.

Leydesdorff, L. (2012) The triple helix, quadruple helix and an n-tuple of helices: explanatory models for analyzing the knowledge-based economy. Journal of the Knowledge Economy, 3, 25-35.

Levin and Cross (2004) The Strength of Weak Ties You Can Trust: The Mediating Role of Trust in Effective Knowledge Transfer. Management Science, 50(11), 1477-1490 Lockett, A., Siegel, D., Wright, M. and Ensley, M.D. (2005) The Creation of Spin-Off Firms at Public Research Institutions: Managerial and Policy Implications. Research Policy, 34 (7), 981-993.

Lockett, A. Wright, M. and Franklin, S. (2003) Technology Transfer and Universities' SpinOut Strategies. Small Business Economics, 20, 185-200.

Lucas, L.M. and Ogilvie, D.T. (2006) Things are not always what they seem: How reputations, culture, and incentives influence knowledge transfer. The Learning Organization, 13(1),7 - 24 .

Lucas, L.M. (2006) The role of culture on knowledge transfer: the case of the multinational corporation. The Learning Organization, 13(3), 257 - 275.

Liyanage, C., Elhag, T., Ballal, T. and Li, Q. (2009) Knowledge communication and translation-a knowledge transfer model. Journal of Knowledge Management, 13(3), 118-131. Matzler, K. and Müller, J. (2011) Antecedents of Knowledge Sharing - Examining the Influence of Learning Orientation and Performance Orientation on Knowledge Sharing. Journal of Economic Psychology, 32(3), 317-329.

McAdam, M., McAdam, R., Galbraith, B., and Miller, K. (2010) An exploratory study of principal Investigator roles in UK university proof-of-concept processes: An absorptive capacity perspective. $R \& D$ Management, 40, 455 .

McAdam, R., Miller, K., McAdam, M. and Teague, S. (2012) The development of University Technology Transfer stakeholder relationships at a regional level: Lessons for the future. Technovation, 32, 57-67.

Miller, K., McAdam, M., McAdam, R. (2014) The changing university business model: A stakeholder perspective. $R \& D$ Management, 44 (3) 265-287. 
Miller, K., Moffett, S., McAdam, R. and Brennan, M. (2011) An exploratory study of retaining and maintaining knowledge in university technology transfer processes. International Journal of Entrepreneurial Behaviour and Research, 17(6), 663-648.

Mitton C., Adair, C.E., McKenzie E, Patten, S.B. and Waye P.B. (2007) Knowledge transfer and exchange: review and synthesis of the literature. Milbank Quarterly, 85 (4):729-68.

Mitchell, R. K., Agle, B. R. and Wood, D. J. (1997) Toward a Theory of Stakeholder Identification and Salience: Defining the Principle of Who and What Really Counts. The Academy of Management Review, 22 (4), 853-886.

Mosey, S. and Wright, M. (2007) From human capital to social capital: A longitudinal study of technology-based academic entrepreneurs. Entrepreneurship Theory and Practice, 31(6), 909-935.

Nadler, J., Thompson, L. and Boven, L.V. (2003) Learning negotiation skills: Four models of knowledge creation and transfer. Management Science, 49(4), 529-540.

Nambisan, S. and Sawhney, M. (2007) The Global Brain: Your Roadmap for Innovating Faster and Smarter in a Networked World. Wharton School Publishing, PA.

Nonaka, I. and von Krogh, G. (2009) Tacit Knowledge and Knowledge Conversion:

Controversy and Advancement in Organizational Knowledge Creation Theory. Organization Science, 20(3), 635-652.

O'Shea, R.P., Chugh, H. and Allen, T.J. (2008) Determinants and consequences of university spinoff activity: A conceptual framework. International Journal of Technology Transfer, 33 (6), 653-666.

RIS (2014) National/Regional Innovation Strategies for Smart Specialisation. Cohesion Policy 2014-2020, European Commission. Available online: http://ec.europa.eu/regional_policy/sources/docgener/informat/2014/smart_specialisation_en. pdf (accessed 10/12/2014).

Rothaermel, F.T., Agung, S.D. and Jiang, L. (2007) University entrepreneurship: A taxonomy of the literature. Industrial and Corporate Change, 16, 691-791.

Sainsbury Report (2007) The Race to the Top: A Review of Government's Science and Innovation Policies. London: HMSO.

Sharifi, H. and Liu, W. (2010) An Exploratory Study of Management of University Knowledge Transfer Offices in the UK. AIM Research. Available online: http://www.aimresearch.org/uploads/File/Publications/Academic\%20Publications\%202 Emerging_landscape.pdf (accessed 19/12/14). 
Siegel, D. S., Waldman, D. and Link, A.N. (2003) Assessing the Impact of Organizational Practices on the Relative Productivity of University Technology Transfer Offices: An Exploratory Study. Research Policy, 32(1): 27-48.

Stake, R.E. (2000) Case studies. In: Denzin, N.K. and Lincoln, Y.S. (eds.), Handbook of Qualitative Research, Thousand Oaks, CA: Sage Publications.

Su, Z., Ahlstrom, D., Li, J. and Cheng, D. (2013) Knowledge creation capability, absorptive capacity, and product innovativeness. R\&D Management, 44 (5), 473-485

Szulanski, G. (1996) Exploring internal stickiness impediments to the transfer of best practice within the firm. Strategic Management Journal, 17, 27-43.

Szulanski, G. (1996) Exploring internal stickiness: Impediments to the transfer of best practice within the firm. Strategic Management Journal, 17: 27-43

Szulanski, G., Cappetta, R. and Jensen, R. J. (2004) When and How Trustworthiness Matters: Knowledge Transfer and the Moderating Effect of Causal Ambiguity. Organization Science, 15(5), 600-613.

Szulanski, G. (2002) Sticky Knowledge: Barriers to Knowing in the Firm. London: Sage.

Swan, J., Bresnen, M., Robertson, M., Newell, S. and Dopson, S. (2010) When Policy meets Practice: Colliding Logics and the Challenges of 'Mode 2' Initiatives in the Translation of Academic Knowledge. Organization Studies, 31(9-10), 1311-1340.

Todorova, G. and Durisin, B. (2007) Absorptive capacity: Valuing a reconceptualization. Academy of Management Review, 32(3): 774-786.

Tortoriello, M. and Krackhardt, D. (2010) Activating cross-boundary knowledge: the role of Simmelian ties in the generation of innovations. Academy of Management Journal, 53(1), 167181.

Urbano, D. and Guerrero, M. (2013) Entrepreneurial Universities: Socioeconomic Impacts of Academic Entrepreneurship in a European Context. Economic Development Quarterly, 27, 4055.

Van Looy, B., Landoni, P., Callaert, J., van Pottelsberghe, B., Sapsalis, E. and Debackere, K. (2011) Entrepreneurial effectiveness of European universities: An empirical assessment of antecedents and trade-offs. Research Policy, 40 (4), 553-564.

Vandekeckhove, W. and Dentchev, N.A. (2005) A network perspective on stakeholder management: Facilitating entrepreneurs in the discovery of opportunities. Journal of Business Ethics, 60, 221-232. 
van Wijk, R., Jansen, J. and Lyles, M. (2008) Inter-and intraorganizational knowledge transfer: a meta-analytic review and assessment of its antecedents and consequences. Journal of Management Studies, 45(4), 830-853.

Volberda, H.W., Foss, N.J. and Lyles, M.A. (2010), Absorbing the Concept of Absorptive Capacity: How to Realize Its Potential in the Organization Field. Organization Science, 21(4), 931-951.

Walter, A.M., Auer, M., Ritter, T. (2006) The impact of network capabilities and entrepreneurial orientation on university spin-off performance. Journal of Business Venturing, 21(4), 541-567.

Wilson, T. (2012) A Review of Business-Industry Collaboration. London: Department for Business, Innovation and Skills. Available https://www.gov.uk/government/uploads/system/uploads/attachment_data/file/32383/12-610wilson-review-business-university-collaboration.pdf (accessed 18/12/2014).

Wright, M., Piva, E., Mosey, S. and Lockett, A. (2009) Academic entrepreneurship and business schools. Journal of Technological Transfer, 34 (6), 560-587.

Yeoh, P. (2009) Realized and potential absorptive capacity: Understanding their antecedents and performance in the sourcing context. Journal of Marketing Theory and Practice, 17(1): 21-36.

Yin, R. K. (2011) Case study research: Design and methods, (4th ed.). Thousand Oaks, CA: Sage.

Zahra, S. A. and George, G. (2002) Absorptive capacity: A review, reconceptualization and Extension. Academy of Management Review, 27(2), 185-203. 


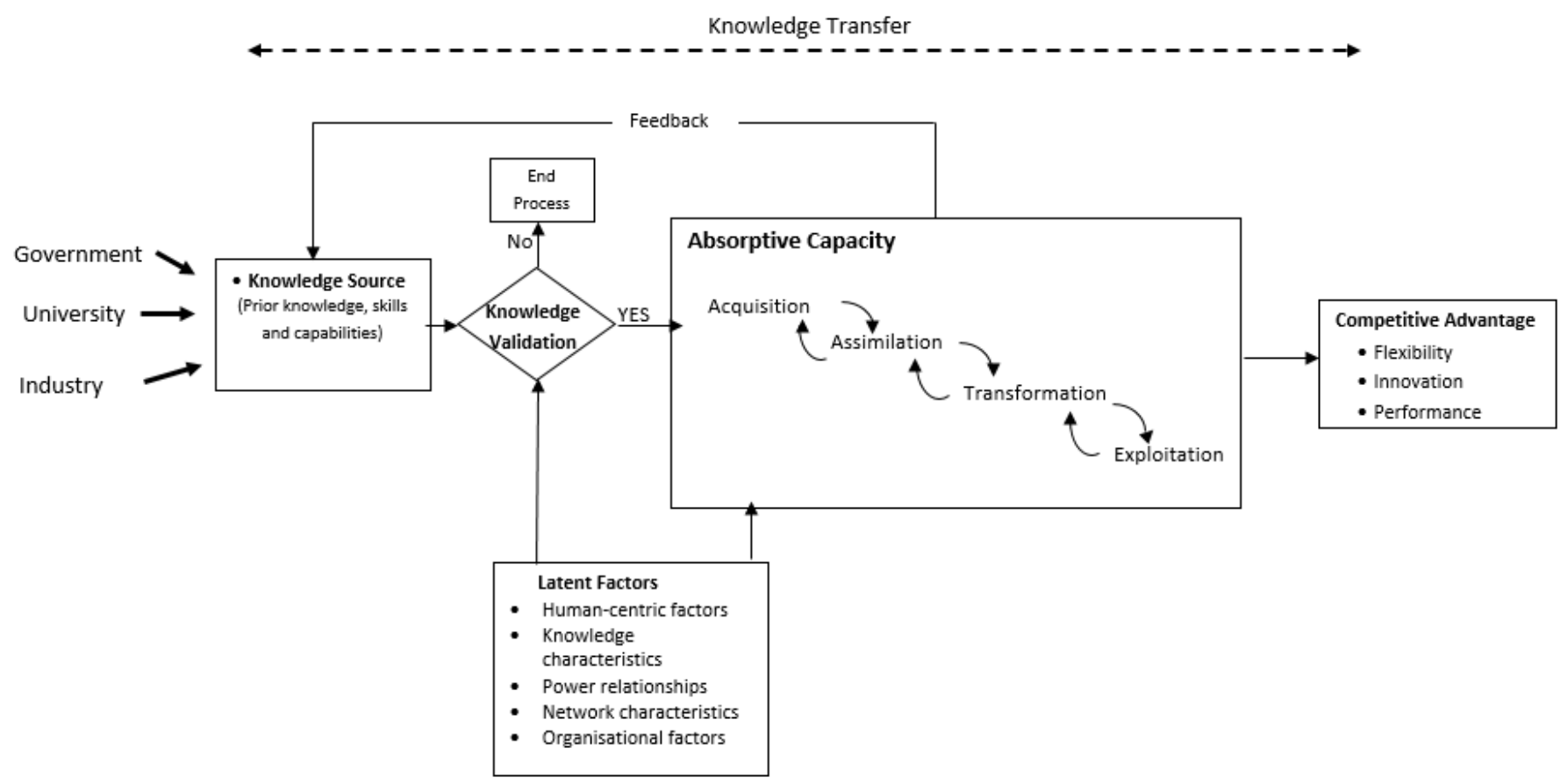

Figure 1: Ex Ante Absorptive Capacity based conceptual framework for knowledge transfer from universities

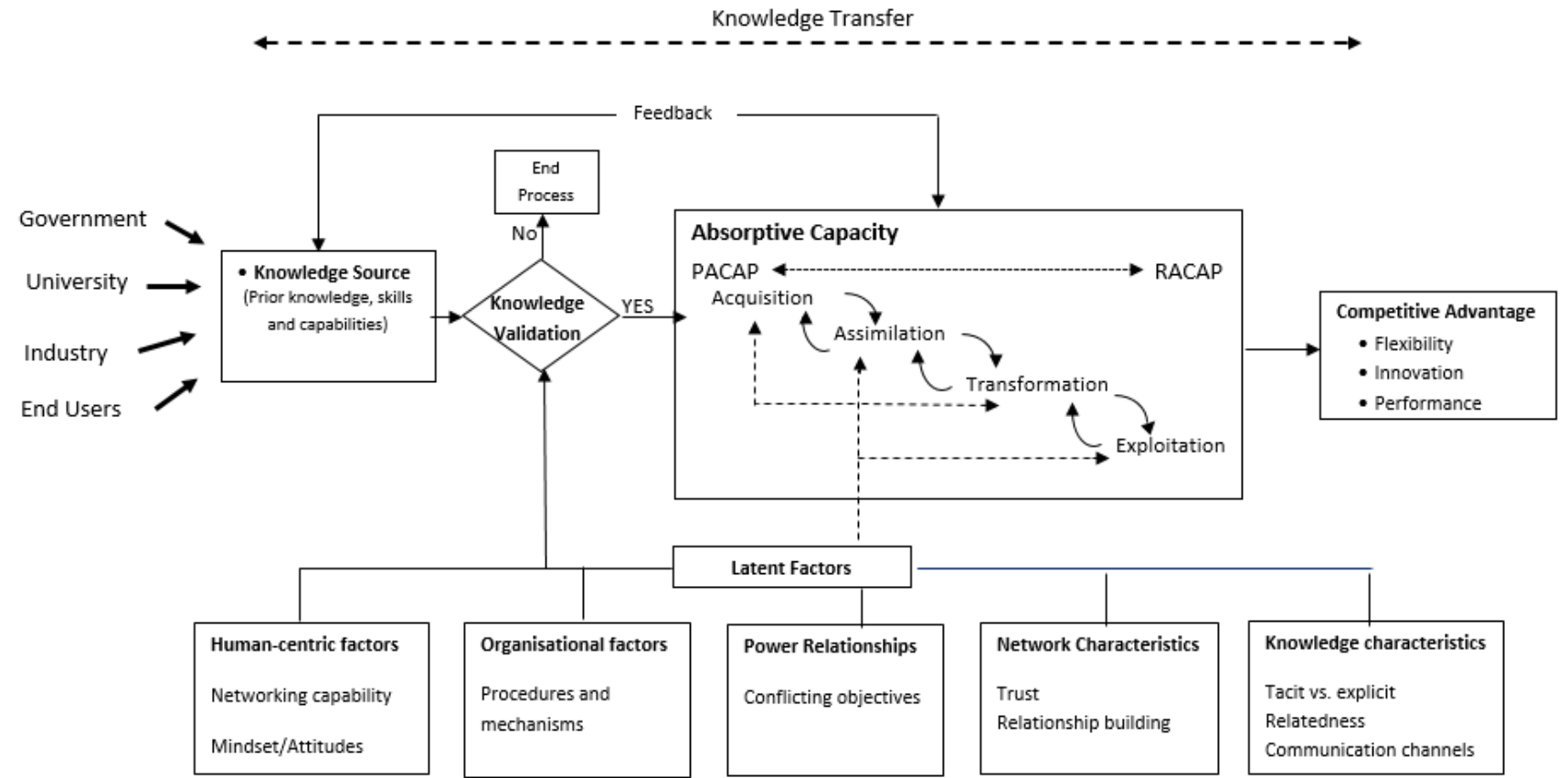

Figure 2: Ex Post Absorptive Capacity based conceptual framework for knowledge transfer from universities 
Table 1: Enablers and Barriers of Knowledge Transfer

\begin{tabular}{|c|c|c|c|}
\hline Theme & $\begin{array}{l}\text { Sub-Theme/Sub } \\
\text { elements }\end{array}$ & Effect on KT & Findings \\
\hline \multirow{3}{*}{$\begin{array}{l}\text { Human-Centric } \\
\text { Factors }\end{array}$} & $\begin{array}{l}\text { Networking } \\
\text { Capability }\end{array}$ & $\begin{array}{l}\text { Positive } \\
\text { /Negative }\end{array}$ & $\begin{array}{l}\text { - The ability to network was thought to be essential in aiding KT activities. However with all capabilities, } \\
\text { the stakeholders, particularly the academics, varied in their abilities to network. } \\
\text { - The unwillingness or ability to engage in networking was found to hinder KT activities. }\end{array}$ \\
\hline & $\begin{array}{ll}\text { Skills } & \text { and } \\
\text { resources }\end{array}$ & Negative & $\begin{array}{l}\text { - Many academics were lacking the skills, and time to network with industry. This meant they often } \\
\text { had RACAP but then lacked the skills and resources to commercialise their technologies (hence } \\
\text { lacking RACAP). }\end{array}$ \\
\hline & Attitudes & $\begin{array}{l}\text { Positive/Neg } \\
\text { ative }\end{array}$ & $\begin{array}{l}\text { - Being opportunistic was an enabler of KT. } \\
\text { - University remit and organisational context was found to hinder engagement in KT. }\end{array}$ \\
\hline \multirow{2}{*}{$\begin{array}{c}\text { Knowledge } \\
\text { Characteristics }\end{array}$} & $\begin{array}{l}\text { Knowledge } \\
\text { Relatedness }\end{array}$ & $\begin{array}{l}\text { Positive/Neg } \\
\text { ative }\end{array}$ & $\begin{array}{l}\text { - Synergy between knowledge sources is needed where there are sufficient knowledge similarity to } \\
\text { aid absorption and internalisation but also a degree of diversity between a knowledge source and } \\
\text { recipient to enhance their willingness to engage in knowledge transfer. } \\
\text { - Diverse knowledge sources can be difficult to absorb and internalise. }\end{array}$ \\
\hline & $\begin{array}{ll}\text { Type } & \text { of } \\
\text { knowledge }\end{array}$ & Negative & $\begin{array}{l}\text { - The main type of knowledge sought was business related knowledge. This ranged from sales, } \\
\text { marketing, finance, legal and experiential business knowledge; which is all inherently tacit and 'sticky' } \\
\text { therefore often hard to acquire, transfer and absorb. } \\
\text { - Some academics feel they have all the knowledge they need to commercialise a technology and do } \\
\text { not need any help - 'not invented here syndrome. } \\
\text { - KTO staff members thought that certain academics were not actively networking enough to gain the } \\
\text { knowledge needed to help commercialise their technologies. }\end{array}$ \\
\hline \multirow[t]{2}{*}{ Power Relationships } & University Remit & Negative & $\begin{array}{l}\text { - The need to balance teaching, research and KT was a challenge. Academics stressed that it was } \\
\text { usually impossible to do all three at the same time due to resource constraints. } \\
\text { - There was a feeling amongst some of the Academics that the university doesn't support technology } \\
\text { KT enough. } \\
\text { - There was more of a push within the university towards teaching and research activities. This } \\
\text { perceived lack of support or pressure could potential negatively influence certain Academics from } \\
\text { engaging in KT for the purposed of open innovation. }\end{array}$ \\
\hline & Incentives & Negative & $\begin{array}{l}\text { - Perceived lack of incentives associated with } \mathrm{KT} \text { negatively influenced both PIs willingness to engage } \\
\text { in UTT and also affected their efforts within KT if they had decided to undertake commercialisation } \\
\text { activities }\end{array}$ \\
\hline
\end{tabular}




\begin{tabular}{|c|c|c|c|}
\hline & $\begin{array}{l}\text { Conflicting } \\
\text { Objectives }\end{array}$ & Negative & $\begin{array}{l}\text { - The KTO, academics and Government all appeared to have varying objectives, with each trying to } \\
\text { exert their power } \\
\text { - While government programmes are beneficial to aiding KT activities the KTO and academics thought } \\
\text { they were not flexible enough due to their time constraints of funding rounds } \\
\text { - There was a lot of disharmony felt between the academics and the KTO in relation to technology } \\
\text { assessments and KTO rules and procedures which de-motivated the academics from future } \\
\text { engagement in KTO activities } \\
\text { - It was felt that the KTO staff did not have the skills to properly assess technologies, that the KTO } \\
\text { process was too slow and that there was not enough incentives to engage with KT activities }\end{array}$ \\
\hline \multirow{5}{*}{$\begin{array}{c}\text { Network } \\
\text { Characteristics }\end{array}$} & Role of KTO & $\begin{array}{l}\text { Positive/ } \\
\text { Negative }\end{array}$ & $\begin{array}{l}\text { - They played the role of a broker and 'boundary spanner' by connecting academics with various } \\
\text { networks and knowledge sources both internal and external to the university } \\
\text { - However, the perceived value of this role varied with some academics thinking the KTO did not do } \\
\text { enough }\end{array}$ \\
\hline & $\begin{array}{l}\text { Role of } \\
\text { Government }\end{array}$ & $\begin{array}{l}\text { Positive/ } \\
\text { Negative }\end{array}$ & $\begin{array}{l}\text { - The role government appeared to play was limited with respect to their interactions with the } \\
\text { academic entrepreneurs, however with regards funding to enhance KT, their role was very important } \\
\text { - However performance measurement were considered to be ambiguous and strict rules for funding } \\
\text { mechanism were found to be restrictive; resulting in missed opportunities }\end{array}$ \\
\hline & $\begin{array}{ll}\text { Role } & \text { of } \\
\text { University }\end{array}$ & Negative & $\begin{array}{l}\text { - The case universities procedures, mechanisms and environment was found to potentially de- } \\
\text { motivate some academic from engaging in knowledge transfer and collaborative innovation activities }\end{array}$ \\
\hline & $\begin{array}{l}\text { Relationship } \\
\text { building }\end{array}$ & Positive & $\begin{array}{l}\text { - The ability to build strong relationships with quadruple helix stakeholder facilitated knowledge } \\
\text { transfer and exchange } \\
\text { - Relationship building led to knowledge access } \\
\text { - Allowed knowledge to be externally retained in networks (relative capacity) }\end{array}$ \\
\hline & Trust & $\begin{array}{l}\text { Positive/ } \\
\text { Negative }\end{array}$ & $\begin{array}{l}\text { - Trust mediated the willingness of stakeholder to engage in } \mathrm{KT} \text {. } \\
\text { - A lack of trust was found to prevents knowledge openness hence limited stakeholder engagement } \\
\text { - Academic rivalry and research pressures resulted in some academics finding it hard to know who to } \\
\text { trust within the university }\end{array}$ \\
\hline $\begin{array}{l}\text { Organisational } \\
\text { Factors }\end{array}$ & $\begin{array}{l}\text { Procedures/ } \\
\text { Mechanisms }\end{array}$ & $\begin{array}{l}\text { Positive/ } \\
\text { Negative }\end{array}$ & $\begin{array}{l}\text { - Dedicated KTO helped bridge KT and communication between quadruple helix stakeholders } \\
\text { - University remit and lack of incentives to engage in open innovation and KT impacted upon academic } \\
\text { entrepreneur's willingness and ability to engage in KT. }\end{array}$ \\
\hline
\end{tabular}


Appendix 1: Profile of Interviewees

\begin{tabular}{|l|l|}
\hline Code & Job title \\
\hline PI1 & Academic entrepreneur/ Principal investigator \\
\hline PI2 & Academic entrepreneur/ Principal investigator \\
\hline PI3 & Academic entrepreneur/ Principal investigator \\
\hline PI4 & Academic entrepreneur/ Principal investigator \\
\hline PI5 & Academic entrepreneur/ Principal investigator \\
\hline PI6 & Academic entrepreneur/ Principal investigator \\
\hline PI7 & Academic entrepreneur/ Principal investigator \\
\hline PI8 & Academic entrepreneur/ Principal investigator \\
\hline PI9 & Academic entrepreneur/ Principal investigator \\
\hline PI10 & Academic entrepreneur/ Principal investigator \\
\hline PI11 & Academic entrepreneur/ Principal investigator \\
\hline PI12 & Academic entrepreneur/ Principal investigator \\
\hline PI13 & Academic entrepreneur/ Principal investigator \\
\hline PI14 & Academic entrepreneur/ Principal investigator \\
\hline EC1 & Enterprise co-ordinator \\
\hline EC2 & Enterprise co-ordinator \\
\hline KTO1 & Operational knowledge transfer office staff \\
\hline KTO2 & Operational knowledge transfer office staff \\
\hline KTO3 & Managerial knowledge transfer office staff \\
\hline KTO4 & Strategic knowledge transfer office staff \\
\hline Gov1 & Government knowledge transfer liaison staff \\
\hline Gov2 & Government knowledge transfer liaison staff \\
\hline Gov3 & Government knowledge transfer liaison staff \\
\hline Gov4 & Government knowledge transfer manager \\
\hline
\end{tabular}

